\title{
GAMBARAN DIMENSI DARI FATHERING SELF-EFFICACY PADA AYAH TUNGGAL YANG MENGASUH ANAK USIA DINI
}

\author{
Christabel Davina Fidelia Montezuma ${ }^{1}$, Fransisca Rosa Mira Lentari² \\ 1,2Fakultas Psikologi, UNIKA Atma Jaya \\ ${ }^{1}$ christabelmontezuma@gmail.com, ${ }^{2}$ fransisca.lentari@atmajaya.ac.id
}

\begin{abstract}
The aim of this research is to describe the dimensions of a single father's fathering self-efficacy that is involved in the nurturing of early childhood children. The subjects of this research consisted of two participants who are single fathers that lives in DKI Jakarta and surrounding areas, and nurtures two early childhood children (age three to five years old). This research was conducted using a qualitative method, and employed a phenomenological approach. Research data was collected by conducting interview that was based on the fathering self-efficacy theory that was introduced by Sevigny. The collected data is then analyzed according to the anaylsis process of qualitative research, which consists of organizing data, coding, categorizing, to finally reach a conclusion. Results of this research showed that the two participants had differing ways on how they conduct their parenting duties and beliefs on their ability to nurture their children. On eight dimensions, the two participants had different appraisal of their abilities and had the same appraisal on one dimension, that is instrumental care and routines. The factors that contribute to the participant's beliefs are the motivation that was given by the participant's surrounding environment, the mental and emotional states of the participant, and how the participant value their role as a father.
\end{abstract}

Keywords: fathering self-efficacy, single father, early childhood

Abstrak. Penelitian ini bertujuan untuk memeroleh gambaran dimensi dari fathering selfefficacy yang dimiliki oleh ayah tunggal yang mengasuh anak usia dini. Penelitian ini melibatkan dua partisipan yang merupakan ayah tunggal yang berdomisili di daerah DKI Jakarta dan sekitarnya, serta memiliki anak usia dini (tiga-lima tahun). Penelitian ini dilakukan menggunakan metode kualitatif, dengan menggunakan pendekatan fenomonologi. Pengumpulan data dilakukan dengan cara melakukan wawancara secara langsung kepada kedua partisipan, dengan menggunakan panduan wawancara yang mengacu pada teori fathering self-efficacy yang dikemukakan oleh Sevigny. Kemudian data yang telah dikumpulkan dianalisa dalam beberapa tahap sesuai dengan tahapan analisis data kualitif, yaitu dengan mengorganisir data, melakukan coding, kategorisasi, hingga akhirnya menemukan kesimpulan. Hasil penelitian menggambarkan bahwa kedua partisipan memiliki cara yang berbeda dalam menjalankan tugas-tugas pengasuhan dan juga penilaian terhadap kemampuan mengasuh anak yang cenderung beragam. Pada delapan dimensi, kedua partisipan memiliki penilaian yang berbeda terhadap kemampuannya, dan memiliki penilaian yang sama pada satu dimensi yaitu instrumental care and routines. Terdapat beberapa faktor yang berperan terhadap keyakinan tersebut, antara lain dorongan yang diberikan oleh lingkungan sekitar, kondisi emosional atau mental dari ayah tunggal, serta pemaknaan yang dimiliki terhadap perannya sebagai ayah. Kata kunci: fathering self-efficacy, ayah tunggal, anak usia dini 


\section{Pendahuluan}

Memiliki keluarga yang utuh dan dapat menjalankan perannya masing- masing merupakan gambaran yang ideal bagi keberfungsian keluarga, namun terdapat beberapa faktor yang dapat menyebabkan tidak tercapainya hal tersebut, antara lain perceraian orangtua dan kematian pasangan (Saikia, 2017). Berbeda dengan perceraian, pengalaman kematian pasangan cenderung memiliki tantangan yang lebih berat bagi pasangan yang ditinggalkan, hal tersebut dapat disebabkan oleh adanya kesedihan yang lebih mendalam serta transisi yang lebih besar (Wiludjeng, 2011). Meskipun demikian orangtua tunggal tetap memiliki tanggung jawab untuk merawat keluarga dan mengasuh anak tanpa mendapatkan dukungan dari pasangannya, hal tersebut dapat menyebabkan mereka mengalami kesulitan untuk merawat, membina, dan memenuhi kebutuhan fisik, perkembangan, maupun pembelajaran anak yang diasuh (Mugove, 2017). Selain itu, pengalaman kematian pasangan juga memiliki tantangan tersendiri bagi laki-laki maupun wanita sebagai orangtua tunggal.

Pada wanita, permasalahan yang umumnya dihadapi sebagai ibu tunggal berkaitan dengan tuntutan untuk menggantikan peran ayah sebagai pencari nafkah dalam keluarga (Glasser \& Navarne dalam Prasetyawati, 2018). Adanya tuntutan untuk memenuhi kebutuhan finansial secara seorang diri cenderung membuat dirinya tertekan dengan tanggung jawab barunya, dan akibatnya cenderung mengalami kecemasan (Prasetyawati, 2018). Sedangkan pada laki-laki, perubahan pola hidup dan tuntutan untuk terlibat dalam kegiatan rumah tangga dan pengasuhan anak cenderung menjadi kesulitan utama bagi seorang ayah tunggal (Olson \& Defrain, dalam Septiningsih \& Cahyanti, 2014).

Budaya patriarki di Indonesia membuat peran tradisional orangtua terbagi menjadi dua aspek, antara lain aspek publik dan aspek domestik (Septiani \& Nasution, 2018). Aspek publik yang melibatkan kegiatan pencarian nafkah cenderung diorientasikan kepada sosok ayah, dan aspek domestik yang melibatkan kegiatan pengasuhan anak cenderung diorientasikan kepada ibu. Akibatnya, seorang ayah cenderung kurang terlibat dalam kegiatan pengasuhan anak dan lebih mempercayakan tanggung jawab pengasuhan kepada sosok ibu (Abdullah dalam Murti, 2013). Hal tersebut dapat menjadi tantangan bagi seorang ayah tunggal, mengingat bahwa ia merupakan satu-satunya orangtua yang berperan untuk mengasuh anak sehingga memiliki tuntutan untuk memenuhi tanggung jawab pengasuhan anak.

Salah satu hal yang berperan penting dalam menentukan peran pengasuhan yang diperlukan dalam keluarga adalah karakteristik anak, dikarenakan pada setiap tahap 
perkembangan anak, orangtua memiliki tugas pengasuhan, ekspektasi, dan respon yang berbeda-beda terhadap anak (Heath, 2017). Ketidakmampuan untuk memenuhi kebutuhan pengasuhan anak pada satu tahap perkembangan berperan besar pada kondisi anak pada tahap perkembangan selanjutnya, dimana anak cenderung dapat mengalami hambatan dalam perkembangannya (Dufur, Howell, Downey, Ainsworth, \& Lapray, 2010).

Santrock (2018) membagi tahap perkembangan anak ke dalam empat tahapan, antara lain infancy (nol-dua tahun) early childhood (tiga-lima tahun), middle and late childhood (enam-11 tahun), dan adolescence (12-18 tahun). Salah satu periode perkembangan anak yang paling menantang bagi orangtua adalah early childhood, yang sering juga disebutkan sebagai periode troublesome age. Hal tersebut disebabkan oleh adanya permasalahan tingkah laku yang ditunjukkan oleh anak seperti tidak taat, iri hati, dan ketakutan yang tidak masuk akal (Jannah, 2015). Selain itu, pada tahap ini seorang anak mulai membentuk dan menyempurnakan konsep-konsep mengenai lingkungan sosial, perilaku yang patut, dan kesadaran serta ekspresi emosi (Havigrust dalam Jannah, 2015). Oleh karena itu keterlibatan orangtua dalam pengasuhan anak pada periode perkembangan ini memiliki peranan penting untuk memastikan bahwa anak memiliki perkembangan secara positif.

Terdapat beberapa hal yang berperan penting terhadap keterlibatan seorang ayah dalam pengasuhan anak, antara lain kesejahteraan psikologis, kepribadian dan sikap ayah, keagamaan, serta unsur kognitif yang dimiliki seorang ayah (Andayani \& Koentjoro, 2004). Akan tetapi unsur kognitif memiliki peranan penting untuk mendorong keterlibatan ayah dalam pengasuhan anak, dimana kepercayaan yang dimiliki oleh seorang ayah terhadap kemampuannya untuk mengasuh anak cenderung meningkatkan keterlibatannya dalam pengasuhan anak (Hardyanti, Karmiyati, \& Hidayati, 2017). Parenting self-efficacy merupakan penilaian yang dimiliki orangtua terhadap kemampuannya untuk menjalani peran sebagai orangtua, dimana penilaian tersebut dapat berperan terhadap sejauh mana ia akan terlibat dalam kegiatan pengasuhan anak (Coleman \& Karraker, 2000).

Seiring dengan berkembangnya penelitian mengenai parenting self-efficacy, Sevigny (2013) mengatakan bahwa dibutuhkan penelitian secara lebih mendalam mengenai parenting self-efficacy pada ayah, hal tersebut disebabkan oleh adanya perbedaan antara konsep parenting self-efficacy antara ayah dan ibu. Berbedanya pemaknaan peran sebagai orangtua antara ayah dan ibu menyebabkan adanya perbedaan tugas-tugas pengasuhan yang dilakukan, oleh karena itu parenting self-efficacy kurang dapat diukur pada ayah karena dimensi-dimensi dalam teori tersebut lebih banyak 
menggambarkan tugas pengasuhan dari seorang ibu (Christianson \& Palkovitz; Lamb; Silverstein, dalam Sevigny, 2013).

Adanya pandangan tersebut mendorong Sevigny (2013) untuk mengembangkan teori dan alat ukur fathering self-efficacy, yang merupakan penilaian seorang ayah mengenai kemampuannya untuk menjalankan peran sebagai ayah. Selain berperan dalam menentukan keterlibat seorang ayah dalam pengasuhan anak, fathering self-efficacy juga berperan penting untuk menentukan ketahanan yang dimiliki seorang ayah untuk menjalankan perannya sebagai ayah, terutama pada saat ia dihadapkan dengan tantangan atau kesulitan (Sevigny, Loutzenhiser, \& McAuslan, 2016).

Fathering self-efficacy terdiri dari beberapa dimensi yang menggambarkan kepercayaan yang dimiliki seorang ayah mengenai kemampuannya untuk memenuhi berbagai tugas dalam pengasuhan anak (Sevigny, Loutzenhiser, \& McAuslan, 2016). Dimensi-dimensi tersebut antara lain adalah teaching, parenting in context, financial responsibilities, safety and protection, discipline and control, nurturing, accessibility, instrumental care and routines, dan play. Terdapat beberapa faktor yang berperan terhadap fathering self-efficacy, antara lain pandangan yang dimiliki seorang ayah terhadap perannya, dukungan yang ia terima dari lingkungan sekitar, serta kondisi emosional seorang ayah (Sevigny, 2010).

Kong dan Kim (2015) mengatakan bahwa ketidakmampuan seorang ayah tunggal untuk menghadapi tuntutan mencari nafkah, mengasuh anak, dan merawat rumah tangga tidak hanya berdampak pada kondisi ayah tunggal secara negatif, namun juga terhadap perkembangan anak secara jangka panjang. Oleh karena itu, penting untuk mengetahui secara lebih mendalam mengenai tantangan dan juga strategi yang dapat mendukung seorang ayah tunggal dalam menjalankan tanggung jawab pengasuhan anak. Meskipun demikian, penelitian mengenai pengalaman maupun tantangan yang dihadapi oleh orangtua tunggal cenderung lebih banyak berfokus kepada pengalaman ibu tunggal, dan kurang diteliti pada ayah tunggal (Chiu et al., 2018).

Selain itu penelitian sebelumnya mengenai fathering self-efficacy dilakukan dengan menggunakan metode kuantitatif, akibatnya pemahaman mengenai bagaimana dimensidimensi dari fathering self-efficacy dioperasionalisasikan menjadi sangat terbatas dan dibutuhkan eksplorasi secara lebih mendalam (Sevigny, 2016). Berdasarkan latar belakang tersebut, penelitian ini bertujuan untuk mengetahui gambaran dimensi dari fathering self-efficacy yang dimiliki oleh seorang ayah tunggal yang mengasuh anak usia dini. 


\section{Metode}

Penelitian ini bertujuan untuk mengeksplorasi dimensi dari fathering self-efficacy agar dapat memahami secara mendalam mengenai penilaian yang dimiliki oleh ayah tunggal terhadap kemampuannya untuk mengasuh anak. Berdasarkan tujuan penelitian tersebut, maka penelitian ini dilakukan dengan menggunakan metode kualitatif. Desain dalam penelitian ini adalah desain fenomenologi, yaitu desain penelitian kualitatif yang bertujuan untuk mendeskripsikan pengalaman subjektif dari masing-masing partisipan mengenai satu fenomena yang sama dan dialami oleh setiap partisipan (Creswell, 2013).

Partisipan dalam penelitian ini berjumlah dua orang dengan karakteristik sebagai berikut: pertama, ayah tunggal yang kehilangan pasangannya akibat meninggal dunia. Partisipan yang akan dilibatkan dalam penelitian ini merupakan laki-laki yang telah menikah dan kehilangan pasangannya akibat meninggal dunia. Hal ini disebabkan adanya perbedaan karakteristik dan tantangan yang dihadapi oleh ayah tunggal akibat bercerai dengan ayah tunggal akibat kematian pasangan. Kedua hal tersebut berperan penting terhadap peranan ayah tunggal dalam mengasuh anak maupun tantangan atau kesulitan yang dihadapi oleh ayah tunggal terkait dengan pengasuhan anak.

Kedua, menjadi ayah tunggal selama minimal satu tahun. Bonanno (2004) mengatakan bahwa pengalaman kehilangan pasangan pada seorang dewasa menyebabkan rasa duka cita dan kecenderungan untuk mengalami kesulitan dalam menjalankan fungsi sehari-hari dengan optimal hingga setidaknya satu tahun. Dengan karakteristik partisipan tersebut, peneliti dapat menghindari kemungkinan partisipan kembali berduka maupun mengalami gangguan dalam fungsi sehari-hari selepas dari proses wawancara.

Ketiga, mengasuh anak yang berusia dini (early childhood) dengan rentang usia tiga sampai lima tahun. Pengasuhan yang diberikan oleh seorang ayah bergantung pada usia dan tahap perkembangan dari anak, hal tersebut disebabkan oleh adanya perbedaan tantangan pada setiap tugas perkembangan. Santrock (2018) mengatakan bahwa seorang anak berada pada tahap perkembangan early childhood ketika ia berusia tiga sampai lima tahun. Tugas pengasuhan pada tahap perkembangan ini cenderung sulit bagi orangtua yang mengasuh, khususnya bagi ayah tunggal. Hal tersebut dapat disebabkan oleh sikap eksplorasi dan perilaku bermasalah yang cenderung ditunjukkan oleh anak berusia dini. Mengetahui pentingnya keterlibatan orangtua dalam pengasuhan dan juga besarnya tantangan yang dihadapi, fathering self- efficacy berperan penting terhadap keterlibatan dan juga ketahanan ayah tunggal dalam mengasuh anak usia dini. 
Dalam penelitian ini, pengumpulan data diperoleh melalui wawancara dengan metode wawancara semi terstruktur mengenai dimensi dalam fathering self-efficacy pada partisipan penelitian ini yaitu ayah tunggal. Walaupun menggunakan panduan wawancara semi terstruktur dalam mengajukan pertanyaan, namun partisipan juga diberi kesempatan untuk mengeksplorasi topik ini melalui pemberian pertanyaan terbuka (Willig, 2013).

Panduan wawancara yang disusun oleh peneliti mengacu pada teori fathering selfefficacy yang dikemukakan oleh Sevigny (2013), pada proses penyusunannya peneliti juga berkonsultasi dan memeroleh feedback dari beberapa psikolog yang merupakan ahli pada bidang terkait dengan psikologi klinis, pengasuhan anak, dan peran laki-laki dalam pengasuhan. Setelah melalui proses revisi dan juga uji coba panduan wawancara dengan beberapa orang yang memenuhi beberapa kriteria partisipan, peneliti menyelesaikan penyusunan panduan wawancara.

Analisis data pada penelitian ini dilakukan dalam beberapa tahap analisis data kualitatif berdasarkan beberapa tokoh (Yin, 2011 ; Creswell, 2013 ; Poerwandari, 2013). Pada tahap pertama, peneliti akan mengoorganisir data untuk kemudian melakukan coding, yaitu menggabungkan data-data relevan ke dalam beberapa kategori informasi (Creswell, 2013). Setelah peneliti menemukan tema-tema besar dari jawaban partisipan, hal tersebut akan dianalisa kesesuaiannya dengan dimensi-dimensi yang terdapat pada teori fathering self-efficacy.

Beberapa upaya dilakukan oleh peneliti untuk mendapatkan partisipan penelitian, antara lain dengan mempublikasikan e-poster informasi penelitian di media sosial, menghubungi berbagai sekolah dan komunitas orang tua tunggal, serta menghubungi rekan-rekan dan keluarga peneliti. Sebelum melakukan wawancara, peneliti terlebih dahulu melakukan pembangunan rapport serta pemberian informed consent kepada partisipan. Hal tersebut dilakukan dengan tujuan agar partisipan merasa nyaman dan mengetahui secara lebih mendalam mengenai fokus dan tujuan penelitian, sehingga partisipan dapat menjalankan proses wawancara secara nyaman dan terbuka. Pelaksanaan penelitian ini memakan waktu sekitar dua bulan dimana pertemuan wawancara dengan setiap partisipan diadakan sebanyak tiga kali, dan durasi dari setiap pertemuan memakan waktu kurang lebih satu setengah hingga dua jam. 
Philanthropy Journal of Psychology

Vol 4 Nomor 1 (2020), 1-24

ISSN 2580-6076 (Print), ISSN 2580-8532 (Online)

\section{Hasil}

Tabel 1. Gambaran Umum Partisipan Penelitian

\begin{tabular}{lll}
\hline Keterangan & Partisipan 1 & Partisipan 2 \\
\hline Usia & 38 & 38 \\
Tahun Menikah & 2006 & 2007 \\
Tahun saat Istri Meninggal & 2017 & 2017 \\
Penyebab Istri Meninggal & Kanker Ovarium & Kanker Serviks \\
Jumlah Anak yang Diasuh & 2 & 2 \\
Usia Anak yang Diasuh & 5 dan 3 tahun & 5 dan 4 tahun \\
Pendidikan Terakhir & S1 Ilmu Komunikasi & S1 Arsitektur \\
Agama & Islam & Tionghoa \\
Suku Bangsa & Jawa & Katolik \\
Anak ke...dari.... Saudara & 2 dari 2 & 1 dari 1 \\
Pekerjaan & Freelance bidang IT & Freelance Kontaktor \\
\hline
\end{tabular}

\section{Latar Belakang Kehidupan}

Partisipan pertama merupakan anak kedua dari dua bersaudara, pada masa kecilnya partisipan pertama merasa bahwa ayahnya tidak terlibat dalam pengasuhan dan mempercayakan ibunya untuk melakukan tugas tersebut. Hal tersebut membuat partisipan pertama merasa asing dengan sosok ayahnya, dan memiliki hubungan yang lebih dekat dengan sang ibu. Meskipun kedua orangtua dari partisipan pertama masih bekerja secara penuh waktu, namun ibu dari partisipan pertama terlibat secara aktif dalam pengasuhan anak. Akan tetapi kesibukan dalam pekerjaan membuat interaksi dan juga waktu bersama antara partisipan pertama dengan sang ibu menjadi cenderung terbatas, walaupun partisipan pertama merasa bahwa ia kurang menerima kasih sayang dari kedua orangtuanya, kasih sayang tersebut ia dapatkan dari sang eyang. Sejak partisipan pertama lahir hingga duduk di bangku tiga SD, ia dirawat oleh sang eyang sehingga mereka memiliki hubungan yang dekat. Meskipun demikian, partisipan pertama merasa bahwa sejak kecil ia memiliki keinginan akan kasih sayang dan perhatian dari sosok ayahnya sendiri. Ketika partisipan pertama melihat kerabat atau saudaranya bermain, bercanda, dan memiliki hubungan dekat dengan ayahnya, partisipan pertama merasa iri dan ingin untuk memiliki hubungan serupa dengan ayahnya sendiri. 
Sejak kecil, partisipan kedua juga tidak memiliki hubungan yang dekat dengan sang ayah, dan lebih dekat dengan sang ibu. Hal tersebut disebabkan oleh sedikitnya waktu yang ia miliki bersama dengan sang ayah, karena ibu dari partisipan kedua merupakan istri kedua dari sang ayah, maka ayah dari partisipan kedua lebih banyak menghabiskan waktu bersama dengan keluarga dari istri pertamanya. Ayah dari partisipan kedua hanya akan mengunjungi partisipan kedua dan meluangkan waktu untuk makan bersama sekitar dua kali dalam seminggu, dalam pertemuan tersebut, partisipan kedua merasa bahwa sang ayah tidak terlalu banyak berinteraksi atau berkegiatan bersama dengan dirinya. Hal tersebut membuatnya sakit hati terhadap sang ayah, dan menjadi lebih dekat dengan sang ibu. Karena ibu dari partisipan kedua juga bekerja, maka partisipan kedua lebih banyak menghabiskan waktu dan diasuh oleh para tante-tantenya. Meskipun ia memiliki hubungan yang baik dengan para tante, namun ia tetap memiliki keinginan untuk mendapatkan kasih sayang yang utuh dari kedua orangtuanya, walaupun hal tersebut tidak pernah ia dapatkan.

Istri dari kedua partisipan meninggal dunia akibat penyakit kanker, dimana istri partisipan pertama meninggal karena kanker ovarium dan istri dari partisipan kedua meninggal akibat penyakit kanker serviks. Menghadapi kematian dari istrinya, partisipan pertama merasa bahwa meskipun ia merasakan kesedihan yang mendalam, namun ia mampu untuk mengatasinya karena ia memiliki perasaan ikhlas untuk melepaskan kepergian istrinya. Adanya bantuan dari ibu mertuanya, saudara, dan kerabat membuat partisipan pertama mampu untuk melanjutkan kehidupan dan mengurus kedua anaknya, meskipun ia merasa bahwa kondisi keluarganya tidak lagi ideal.

Hal tersebut cukup berbeda dengan partisipan kedua, setelah istri dari partisipan kedua meninggal dunia, ia merasakan kesedihan yang sangat mendalam sehingga membuatnya merasa tidak mampu untuk melanjutkan kehidupannya. Akibatnya selama kurang lebih setahun, partisipan kedua tidak bekerja dan lebih banyak menghabiskan waktu di rumah untuk mengurung diri di kamarnya. Seringkali ketika partisipan kedua teringat akan almarhum istrinya, ia menangis dan merasa hancur. Akan tetapi setelah setahun ia lewati, partisipan kedua mulai berusaha untuk membangun kehidupannya kembali dengan cara mengatasi kesedihan. Beberapa upaya yang dilakukan adalah dengan bermain billiard dan bersosialisasi dengan rekan-rekannya, akibatnya partisipan kedua merasa bahwa ia dapat mengatasi kesedihannya, dan kembali untuk bekerja.

Berkaitan dengan kondisi keluarga pada saat ini, kedua partisipan merasa bahwa kondisi keluarga yang dialami cenderung tidak ideal. Kedua partisipan memiliki dua orang 
anak berusia dini, partisipan pertama memiliki dua anak perempuan sedangkan partisipan kedua memiliki satu anak perempuan dan anak lelaki. Saat ini kedua partisipan belum menikah kembali, hal tersebut membuat kedua partisipan merasa bahwa terdapat keberfungsian keluarga yang cenderung pincang, dimana sosok ibu yang dinilai berperan untuk mengasuh anak dan merawat rumah tangga tidak ada. Meskipun partisipan pertama berusaha untuk beradaptasi dengan peran serta tanggung jawab barunya sebagai ayah tunggal, partisipan kedua cenderung mengandalkan sosok lain untuk mengisi peran ibu yang tidak ada dalam keluarganya.

\section{Teaching}

Dimensi teaching menjelaskan mengenai keyakinan ayah dalam menjalankan perannya untuk memberikan berbagai pembelajaran mengenai dunia dan juga memfasilitasi proses pembelajaran sang anak.

Saat ini salah satu anak dari partisipan pertama telah bersekolah, akan tetapi anaknya yang berusia tiga tahun belum mulai bersekolah. Untuk membantu kegiatan belajar kedua anaknya, partisipan pertama akan membantu anak yang sudah bersekolah untuk belajar mengenai cara baca-tulis. Selain itu kepada kedua anaknya, partisipan pertama secara rutin menanamkan nilai-nilai kebersihan dan kesopanan, serta pengetahuan umum. Partisipan pertama merasa bahwa sebagai ayah tunggal, ia mengalami keadaan yang tidak ideal karena ia menilai anak-anak di sekolah yang memiliki orangtua lengkap cenderung memiliki performa kerja yang lebih baik karena dibantu oleh ibu secara konsisten.

Menurut partisipan pertama, hal tersebut ia lakukan karena ia memiliki keinginan untuk menjadi sosok pertama yang mengajarkan segala sesuatu kepada anaknya. Sebagai ayah, ia tidak ingin kalau anaknya belajar sesuatu yang baru bukan dari dirinya, tetapi dipelajari dari orang lain. Walaupun partisipan pertama merasa kesulitan untuk memenuhi tanggung jawab mengajar anak tanpa adanya sosok istri, akan tetapi adanya bantuan dari lingkungan sekitarnya seperti mertua, saudara, maupun teman-teman membuat kedua anaknya dapat menerima pembelajaran yang dinilai cukup baik. Secara umum, partisipan pertama merasa bahwa ia mampu untuk melakukan tugas tersebut.

Ya aku sih.. yakin sih, yakin. Yakin dalam artian, dengan cara apapun, dua anak ini bisa dapet ilmu yang bagus, yang bermanfaat, meskipun dengan bantuan dari orang lain. Akhirnya aku ngalahnya dengan gitu, jadi aku kenalin-kenalin mereka ke temen 
Philanthropy Journal of Psychology

Vol 4 Nomor 1 (2020), 1-24

ISSN 2580-6076 (Print), ISSN 2580-8532 (Online)

yang ehh.. seneng-atau sayang sama mereka gitu ya.. ya jadi, aku caranya selain ngajarin rumah tapi juga nemuinnya dengan orang-orang yang baik, orang- orang yang bisa dicontoh gitu sih.

Sedangkan bagi partisipan kedua, saat ini kedua anaknya telah bersekolah di sebuah sekolah swasta di daerah Jakarta. Beberapa pelajaran yang telah dipelajari oleh kedua anaknya adalah matematika, bahasa Inggris, dan bahasa Indonesia. Akan tetapi partisipan kedua menilai bahwa dirinya tidak banyak membantu kedua anaknya untuk belajar, dikarenakan ia lebih banyak menghabiskan waktu di luar rumah untuk bekerja ataupun bersosialisasi dengan teman-temannya, akibatnya ia mempercayakan tugas tersebut kepada pengasuh anak.

Bahkan ujian aja saya udah gak ngajarin, suster saya yang ngajarin. Tapi saya pantau nilai akademisnya bagus yaudah lanjutin deh hahaha kalau nilainya jelek baru saya ajarin.

Walaupun partisipan kedua pada awalnya mengajarkan nilai-nilai agama dengan cara mengajarkan anak untuk berdoa, namun saat ini pun hal tersebut tidak terlalu sering dilakukan karena ia menilai kedua anaknya telah mampu untuk melakukan tugas tersebut. Partisipan kedua merasa bahwa sebagai ayah ia tidak terlalu kompeten untuk melakukan tugas tersebut karena sejak dulu hal tersebut dilakukan oleh sang istri dan ia menilai bahwa tanggung jawab tersebut lebih sesuai untuk sosok istri. Hal tersebut membuat partisipan kedua cenderung merasa tidak yakin terhadap kemampuannya untuk melakukan tugas tersebut.

\section{Parenting in Context}

Dimensi parenting in context menjelaskan mengenai keyakinan seorang ayah untuk melakukan pengasuhan anak dalam konteks hubungan dengan pasangan, dan sesuai dengan hasil negosiasi dengan pasangan mengenai peran serta tugas yang menjadi miliknya. Gaya pengasuhan yang diterapkan kepada anak pada umumnya juga akan dipengaruhi oleh lingkungan sosio-historis dari suami istri, sebagai contoh pengalaman pengasuhan yang dialami pada saat masih kecil.

Dalam melakukan pengasuhan saat ini, partisipan pertama banyak menyesuaikan cara yang dilakukan berdasarkan evaluasinya terhadap pengasuhan yang dilakukannya 
pada saat ia mengasuh anak bersama dengan almarhum istrinya. Partisipan pertama tidak banyak mendiskusikan cara mengasuh anak dengan lingkungan sekitar seperti dengan ibu mertua ataupun saudara iparnya, tetapi ia lebih banyak memikirkan seorang diri dan belajar dari pengalamannya mengasuh anak, hal tersebut membuat dirinya mampu menyesuaikan cara pengasuhan yang dilakukan.

Gak ada yang baku sih, kita ngikutin aja-ketemunya apa. "oh gini bagus ya!" yaudah kita gitu.. sambil dilakuin aja, tapi gak ada yang misalkan ada beberapa temen aku yang ada bukunya gitu, mereka ada bukunya ayah harus ngapain ibu harus ngapain-cape deh.

Partisipan pertama menilai bahwa meskipun saat ini keadaan sebagai ayah tunggal tidak ideal bagi dirinya untuk menjalankan pengasuhan, akan tetapi dengan adanya pengalaman di masa kecil dimana ia memperhatikan pengasuhan yang dilakukan oleh orangtuanya membantu partisipan pertama untuk melakukan penilaian terhadap strategistrategi pengasuhan yang dinilai baik. Selain itu, adanya keinginan partisipan pertama untuk terlibat secara langsung dalam pengasuhan anak membuat dirinya berusaha untuk terus belajar dan mencari cara pengasuhan yang positif bagi anak-anaknya. Hal tersebut membuat ia merasa yakin terhadap kemampuannya untuk melakukan tugas tersebut.

Sedangkan bagi partisipan kedua, saat ini pengasuhan dilakukan dengan cara mempercayakan seluruh tugas pengasuhan sepenuhnya kepada pengasuh anak. Partisipan kedua menilai bahwa sebelumnya pengasuhan anak lebih banyak dilakukan dan dikoordinir oleh almarhum istrinya, sehingga ia tidak terlalu banyak terlibat untuk melakukan pengasuhan anak. Hingga saat ini, partisipan kedua merasa bahwa kebanyakan tanggung jawab pengasuhan yang ia hadapi hanya bisa dilakukan oleh sosok ibu. Oleh karena itu, partisipan kedua lebih memilih untuk mempercayakan pengasuh anak. Adanya rasa tidak nyaman untuk melakukan tugas-tugas pengasuhan anak membuat partisipan kedua cenderung menghindari tanggung jawab tersebut, akibatnya ia merasa kurang yakin terhadap kemampuannya untuk melakukan pengasuhan anak tanpa adanya hubungan atau negosiasi dengan istri.

Saya namanya gak bisa-mungkin kamu tau ya, yang namanya single parent, istri itu bisa menjadi bapak rumah tangga, tapi kalau suami belum tentu bisa jadi ibu rumah tangga. Istri biasa urus rumah tangga disuruh kerja bisa, tapi suami disuruh 
Philanthropy Journal of Psychology

Vol 4 Nomor 1 (2020), 1-24

ISSN 2580-6076 (Print), ISSN 2580-8532 (Online)

kerja bisa, disuruh urus rumah tangga belom tentu bisa, belom tentu becus. Saya gak mau membenarkan hal itu, tapi saya ngerasa gak bisa gitu loh.

\section{Financial Responsibilities}

Dimensi ini menjelaskan mengenai keyakinan ayah untuk menyediakan kebutuhan finansial dari keluarga, memastikan bahwa kebutuhan tersebut dipenuhi, dan perencanaan rancangan finansial jangka panjang yang dilakukan.

Saat ini partisipan pertama bekerja secara freelance dalam bidang IT, ia memutuskan untuk mengubah pekerjaan dari yang sebelumnya di bidang asuransi secara penuh waktu. Hal tersebut ia lakukan karena ia merasa bahwa apabila ia tetap bekerja secara penuh waktu, maka kedua anaknya tidak bisa menerima pengasuhan dan perhatian yang dibutuhkan. Partisipan pertama juga merasa bahwa pada pekerjaan sebelumnya ia merasa lebih tertekan, dikarenakan tuntutan pekerjaan yang sangat besar dan juga tekanan karena ia terus menerus mengkhawatirkan keadaan anaknya. Oleh karena itu, partisipan pertama memutuskan untuk mengubah pekerjaannya agar ia dapat membagi waktu dengan lebih mudah untuk bekerja dan mengasuh anaknya.

Partisipan pertama menilai bahwa saat ini ia harus melakukan penyesuaian terkait pengelolaan kondisi finansialnya, meskipun ia merasa puas dengan pekerjaan saat ini namun ia merasa bahwa pekerjaan tersebut cukup menantang karena gaji yang diterima cenderung tidak menetap. Oleh karena itu, untuk mencukupi kebutuhan keluarganya, partisipan pertama mengurangi kecenderungannya untuk bersikap konsumtif dan melakukan kegiatan-kegiatan rekreasional di luar rumah. Walaupun pada awalnya ia merasa kesulitan karena tidak ada sosok istri yang dapat mengingatkannya, namun saat ini ia merasa cukup mampu untuk melakukan tugas tersebut.

Tapi intinya dulu pas aku punya ibunya aku tuh ada yang ngerem, tapi kalau sekarang ehh enggak ada. Jadi itu yang paling challenging gimana caranya aku cari solusi supaya gak konsumtif.

Partisipan kedua saat ini bekerja secara freelance dalam bidang kontraktor, akan tetapi ia merasa bahwa saat ini pekerjaannya kurang menguntungkan karena sedikitnya proyek yang ia dapatkan, oleh karena itu partisipan kedua berusaha untuk mencari peluang-peluang kerja yang baru. Setiap bulannya, partisipan kedua merasa bahwa pendapatannya masih belum cukup untuk memenuhi kebutuhan keuangannya. Meskipun 
kebutuhan untuk rumah tangga tidak terlalu besar, namun kecenderungan partisipan kedua menggunakan banyak uang untuk kegiatan rekreasi membuatnya mengalami kekurangan. Setelah kematian almarhum istrinya, partisipan kedua juga mengalami kejatuhan finansial yang sangat signifikan. Hingga hari ini partisipan kedua merasa belum mampu untuk kembali ke kondisi finansial yang seperti sebelumnya, akibatnya ia cenderung merasa rendah diri dan gagal sebagai pemimpin keluarga. Hal tersebut membuat partisipan kedua merasa tidak yakin terhadap kemampuannya untuk melakukan tugas tersebut.

Saya jauh lebih minder dibanding dulu. Saya merasa yaa merasa kayak diri gak guna kerjaannya cuma-ya saya sadar itu, kerjaannya cuma happy-happy aja semenjak ditinggal istri, bahkan anak bagi saya gak terlalu keurus karena gak ada istri gitu. Kalau diomongin soal kondisi finansial, ya saya jauh lebih minder.

\section{Safety and Protection}

Dimensi ini menjelaskan mengenai keyakinan ayah untuk memiliki kesadaran mengenai lingkungan sekitar anak, dan memastikan keamanan fisik serta emosional dari anak yang diasuh. Beberapa resiko keamanan yang dihadapi oleh anak usia dini antara lain berkaitan dengan keamanan secara fisik, kesehatan, maupun relasi dengan lingkungan sekitar.

Partisipan pertama saat ini rutin untuk mendampingi kegiatan-kegiatan kedua anaknya, baik ketika mereka pergi untuk les ataupun bermain di rumah teman-temannya. Setiap harinya partisipan pertama akan mengantar anaknya ke sekolah, dan juga mengenalkan kedua anaknya kepada anak-anak dari temannya. Partisipan pertama mengenal dengan baik sosok yang dekat dengan kedua anaknya, dan menjaga kedua anaknya dari lingkungan yang dinilai kurang baik pengaruhnya.

iya nungguin.. dan pastinya ngeliatin gitu, walaupun aku pastinya ngobrol sama temen-temen aku tapi tetep ngeliatin.. karena aku takutnya, ya pasti nanti suatu saat terjadi itu nanti konflik sama anak gitu, anak-anak lain.

Hal tersebut ia lakukan karena ia merasa bertanggung jawab akan keamanan dari kedua anaknya, walaupun saat ini ia mengalami tantangan untuk melakukan seorang diri, namun partisipan pertama merasa mampu untuk melakukan tugas tersebut. 
Partisipan kedua saat ini lebih banyak menghabiskan waktu di luar rumah, meskipun ia menyadari bahwa kedua anaknya membutuhkan perhatian dan pengawasan, akan tetapi hal tersebut dirasa sulit untuk ia lakukan saat ini. Oleh karena itu, partisipan kedua memberikan tanggung jawab untuk menjaga anak sepenuhnya kepada pengasuh anak.

Saya udah percayain semuanya sama suster, suster saya apa ya? Cukup vokal dan kalau sama anak gak lembek, tegas suster saya, makanya saya suka suster saya dan saya percayakan ke dia

Partisipan kedua juga berusaha untuk memantau keadaan anaknya dengan cara memasang CCTV, hal tersebut ia lakukan agar ia tetap bisa melihat keadaan anaknya meskipun ia tidak berada di rumah. Partisipan kedua merasa tidak nyaman apabila ia harus menghabiskan waktu bersama dengan anak-anaknya di rumah, akibatnya ia merasa tidak mampu untuk melakukan tugas tersebut. Berkaitan dengan keyakinannya untuk melakukan tugas pengasuhan tersebut, ia cenderung merasa tidak yakin terhadap kemampuannya.

\section{Discipline and Control}

Dimensi ini menjelaskan keyakinan ayah untuk memberikan disiplin kepada anakanak yang diasuh melalui penetapan aturan dan pemberian konsekuensi bagi perilaku anak. Bagi anak usia dini, disiplin dan kontrol dilakukan sebagai upaya agar anak yang diasuh tidak melakukan kenakalan atau perilaku buruk.

Partisipan pertama menilai bahwa kedua anaknya memiliki rasa ingin tahu yang sangat tinggi, seringkali mereka mau mengeksplorasi berbagai kegiatan seperti bermain game, menggunakan gadget, dan sebagainya. Hal tersebut tidak dilarang oleh partisipan pertama, tetapi ia lebih banyak membatasi kegiatan tersebut dan memberikan pengertian kepada anak. Beberapa kali partisipan pertama melihat ketika keponakan atau anak-anak dari temannya dididik secara terlalu keras, mereka justru melakukan perilaku yang sangat nakal ketika tidak bersama dengan orangtuanya. Oleh karena itu, ia lebih banyak menjelaskan perilaku yang pantas dan tidak pantas dilakukan kepada anak, serta membatasi aktivitas bermain gadget agar tidak memberikan dampak yang negatif.

Mmm.. tapi di luar, anak-anaknya ketika main sama kita, gak ada orangtuanya- khususnya gak ada ibunya, itu jadi-jadi ngeloss. Jadi dia kayak 
Philanthropy Journal of Psychology

Vol 4 Nomor 1 (2020), 1-24

ISSN 2580-6076 (Print), ISSN 2580-8532 (Online)

ngerasa bebas gitu kali yah? "yes gak ada nyokab gue nih jadi gak ada yang marahin" dan aku gak mau kayak gitu.

Meskipun partisipan pertama tidak membuat aturan-aturan tertentu dalam rumah tangga, namun ia merasa bahwa dengan caranya saat ini, hal tersebut sudah mendorong anak untuk tidak melakukan perilaku yang kurang baik. Dengan adanya pengalaman belajar baik dari pengalaman pengasuhannya di masa lalu mendorongnya untuk mampu mengetahui cara menerapkan disiplin yang baik, partisipan pertama cenderung merasa mampu untuk melakukan tugas tersebut.

Bagi partisipan kedua, disiplin diterapkan dengan cara membatasi kegiatan yang dinilai kurang bermanfaat bagi anak, yaitu bermain gadget dan juga menonton televisi. Ketika anak melakukan perilaku yang dinilai tidak baik, partisipan kedua akan memberikan teguran keras dan juga memberikan ancaman hukuman kepada anak. Akan tetapi saat ini partisipan kedua merasa bahwa hal tersebut jarang ia lakukan, rasa tidak nyaman untuk meluangkan waktu bersama anak membuatnya lebih banyak mencari kegiatan di luar rumah. Oleh karena itu partisipan kedua lebih mempercayakan tugas pemberian disiplin kepada pengasuh anak, berkaitan dengan keyakinannya, ia merasa kurang yakin untuk melakukan tugas tersebut.

Karena saya jarang di rumah, jadi lebih longgar untuk menerapkan disiplinnya.. karena saya jarang ketemu si Rudi, tadi saya cuma liat mereka di rumah dari CCTV aja saya nonton. Ohh mereka lagi begini.. ya sejauh ini sih suster saya masih bisa handle mereka karena suster saya galak

\section{Nurturing}

Dimensi ini menjelaskan mengenai keyakinan ayah untuk memberikan kasih sayang dan afeksi kepada anak yang diasuh. Berbeda dengan tahap perkembangan sebelumnya, anak berusia dini sudah mulai memiliki kesadaran mengenai sikap dan emosi dari orang lain serta mampu untuk meresponi hal tersebut, oleh karena itu anak usia dini mulai dapat memahami kasih sayang yang diberikan oleh orang orangtuanya kepada dirinya.

Partisipan pertama menilai bahwa dirinya memiliki hubungan yang sangat dekat dengan kedua anaknya, seringkali ia memeluk, mencium, dan menggendong anaknya. Partisipan pertama merasa bahwa hal tersebut sudah biasa ia lakukan sehingga sudah 
menjadi kebiasaan bagi mereka, selain itu kedua anaknya seringkali bercerita kepada dirinya mengenai segala sesuatu yang mereka alami sehari-hari. Menurut partisipan pertama ia memiliki keinginan untuk membangun hubungan yang dekat dengan kedua anaknya, sebagai ayah, ia merasa bahwa ia bertanggung jawab untuk menjadi sosok yang bisa diandalkan oleh kedua anaknya. Saat ini partisipan pertama menikmati waktu bersama dengan kedua anaknya, dan merasa mampu untuk melakukan tugas tersebut.

Mmm.. yaaa.. lebih aku lebih senengnya ngasih tau ke mereka, apapun yang mereka butuh pertolongan, ngasih hintnya lebih kayak ayah yang harus kalian datengin gitu. Ehh jadi kayak.. ehh.. ya ya maksudnya ngasih sayang tuh, aku pengen siapapunapapun yang mereka alami itu tuh ehh supaya memberikan informasi ke aku ini.

Partisipan kedua merasa bahwa ia dan kedua anaknya memiliki hubungan yang tidak terlalu dekat, mereka tidak lagi melakukan berbagai kegiatan bersama. Untuk mengekspresikan kasih sayang kepada anak-anaknya, partisipan kedua lebih banyak memberikan barang-barang yang diinginkan oleh anaknya. Akan tetapi ia merasa tidak terbiasa maupun mampu untuk memberikan kasih sayang dalam bentuk menghabiskan waktu bersama anak, meskipun ia merasa bahwa hal tersebut merupakan cara yang ideal. Partisipan kedua merasa bahwa ia membutuhkan bantuan dari seorang pasangan untuk memberikan kasih sayang kepada anak-anaknya, oleh karena itu ia merasa tidak yakin terhadap kemampuannya untuk memberikan kasih sayang kepada anak-anaknya.

Dalam kondisi seperti ini saya gak mampu. Saya sadar kok saya sering angkat tangan, saya sadar. Gak baik menurut saya, saya tau. Cuma kadang saya.. mencari kegiatan di luar yang menyenangkan hati saya

\section{Instrumental Care and Routines}

Dimensi ini menjelaskan mengenai keyakinan ayah untuk berperan dalam mengurus kebutuhan dan rutinitas sehari-hari dari anak yang diasuh. Pada anak usia dini, meskipun kemampuan motorik dan kemampuan berpikir mereka sudah berkembang lebih pesat, namun keterampilan mereka untuk melakukan kegiatan sehari-hari masih terbatas sehingga masih membutuhkan bantuan dari orang yang lebih dewasa.

Setiap harinya partisipan pertama mengurus kebutuhan sehari-hari anaknya mulai dari menyiapkan makanan pagi, memandikan, membantu menyiapkan pakaian, dan 
sebagainya. Meskipun ia tinggal bersama ibu mertua dan seorang pembantu, namun sebagian besar kebutuhan harian merupakan tanggung jawab partisipan pertama. Akan tetapi dalam pelaksanaannya, partisipan pertama merasa kesulitan walaupun ia masih menjalankan tugas tersebut sampai hari ini. Partisipan pertama merasa bahwa kemampuan yang ia miliki cenderung terbatas karena tidak terbiasa, ia juga seringkali merasa lelah, kurang sabar, dan merasa ragu terhadap kemampuannya untuk melakukan tugas tersebut secara jangka panjang.

Lebih ke kesabaran sih.. aku.. yaa kadang kadang dipress banget tuh kesabaran, itu yang paling dibutuhkan banget untuk menghadapi mereka berdua sehari-hari.

Partisipan pertama menilai bahwa dalam jangka panjang, ia akan membutuhkan bantuan dari pasangan untuk melakukan tugas tersebut. Oleh karena itu, partisipan pertama merasa tidak yakin terhadap kemampuannya untuk melakukan tugas tersebut.

Sedangkan bagi partisipan kedua, setiap hari ia hanya akan mengantar dan menjemput kedua anaknya dari sekolah. Akan tetapi untuk seluruh kebutuhan lain anaknya, ia mempercayakan hal tersebut kepada pengasuh anak. Menurut partisipan kedua, sejak dahulu ia tidak pernah terbiasa untuk memenuhi tugas pengasuhan tersebut, akibatnya hingga saat ini ia merasa bahwa tugas tersebut merupakan tanggung jawab dari sosok istri dalam rumah tangga. Adanya rasa tidak mampu dan tidak yakin terhadap kemampuannya mendorong partisipan kedua untuk menghindari tanggung jawab tersebut, dan mempercayakan sepenuhnya kepada pengasuh anak.

Situasinya ya sebenernya yang bikin saya ngerasa gak mampu sejak saya ditinggal istri saya, sejak itu saya sebenernya udah gak terlalu fokus sama anak. Karena terutama buat anak bagi saya udah ada yang ngurus, anter mereka sekolah, jemput lagi, udah abis itu saya gak mau terlalu pusing dengan kegiatan mereka apa. Lebih banyak sama dunia saya sendiri.

\section{Accessibility}

Dimensi ini menjelaskan mengenai keyakinan ayah untuk hadir bagi anak dan berinteraksi dengan anak yang diasuh. Hal yang penting dalam mengasuh anak usia dini bukan hanya waktu yang diluangkan bersama dengan anak, namun juga kualitas dari waktu serta hubungan yang dimiliki bersama anak. Selain itu bagi anak usia dini, 
banyaknya waktu yang diluangkan bersama dengan orangtua juga akan turut berperan dalam menentukan kedalaman relasi antara orangtua dengan anak.

Partisipan pertama menilai bahwa saat ini ia banyak menghabiskan waktu bersama dengan kedua anaknya untuk berkegiatan bersama, dengan pekerjaan yang bersifat freelance, partisipan pertama merasa ia dapat meluangkan lebih banyak waktu bersama dengan anak-anaknya.

Karena waktu di kerja kantoranya itu, di satu tahun terakhir bener-bener stresfull mikirin anak di rumah, eyang yang gak tambah muda, dan waktu yang terlewat untuk sama-sama mereka.. gitu. Dan itu bener-bener berdampak banget sama pekerjaan di kantor.

Partisipan pertama merasa hal tersebut sangat baik karena ia dapat mendampingi kedua anaknya untuk bermain, belajar, atau berbincang-bincang bersama. Partisipan pertama merasa bahwa hal tersebut dapat dilakukan setelah dirinya melakukan penyesuaian, ia merasa sebagai ayah, dirinya bertanggung jawab untuk membangun hubungan yang dekat dan membuat kedua anaknya merasa nyaman. Adanya keinginan tersebut membuat partisipan pertama merasa lebih yakin untuk mengubah pekerjaannya, dan ia merasa yakin terhadap kemampuannya untuk melakukan tugas tersebut.

Akan tetapi berbeda dengan partisipan pertama, saat ini partisipan kedua merasa bahwa hubungannya dengan kedua anaknya menjadi tidak terlalu dekat karena seringkali ia tidak memiliki waktu untuk anak-anaknya. Partisipan kedua menilai bahwa kedua anaknya lebih banyak menghabiskan waktu bersama dengan tante dari partisipan kedua atau pengasuh anak, partisipan kedua merasa bahwa ia tidak bisa meluangkan waktu dengan kedua anaknya karena ia merasa tidak nyaman dan juga bosan ketika menghabiskan waktu dengan anak. Oleh karena itu, partisipan kedua lebih memilih untuk menghabiskan waktu dengan teman-temannya untuk mencari kesenangan di luar rumah. Adanya rasa tidak yakin yang dialami partisipan kedua membuat menghindari tugas tersebut, dan lebih mempercayakan sosok pengasuh anak dan tantenya sendiri.

Gak betah, gak betah di rumah. Karena dulu yang bisa bikin saya betah karena ada istri, istri saya bisa kasih kegiatan, ataupun kalau gak ada kita bisa main game atau baca buku. Saya bisa main game di handphone, main di rumah, main game di PC di 
Philanthropy Journal of Psychology

Vol 4 Nomor 1 (2020), 1-24

ISSN 2580-6076 (Print), ISSN 2580-8532 (Online)

komputer, itu saya lakukan. Cuma walaupun dulu saya lakukan, sekarang saya bosen untuk main game. Gak tau kenapa rasanya udah berubah aja

Play

Dimensi ini menjelaskan mengenai keyakinan ayah untuk memberikan dan melakukan permainan yang sesuai dengan anak yang diasuh. Pada anak usia dini, bermain merupakan kegiatan yang dapat menjadi rekreasi dan juga mengasah kemampuan kognitif serta sosio-emosional dari sang anak.

Partisipan pertama aktif untuk melakukan kegiatan bermain dengan anak, seringkali ia menyediakan permainan-permainan seperti boardgames untuk kedua anaknya. Untuk mencari permainan bagi kedua anaknya partisipan pertama seringkali mencari informasi mengenai permainan yang menarik namun juga edukatif kepada teman-temannya yang juga memiliki anak seusia dengan kedua anaknya, ia merasa bahwa tidak baik apabila ia hanya memilih permainan yang tidak menambahkan nilai atau pembelajaran bagi kedua anaknya. Partisipan pertama juga belajar mengenai cara memilih permainan melalui bagaimana almarhum istrinya memilih permainan bagi anak-anaknya, oleh karena itu partisipan pertama mampu memberikan permainan yang disukai oleh kedua anaknya.

Cukup yakin lah, gak ada masalah. Gak ada yang terlalu.. yaa pada prinsipnya aku bisa ngerem sih, kalau aku liat rumi download sesuatu yang kurang bagus aku dengan gampangnya bisa bilang ke dia "jangan yang ini deh, ini permainannya kurang bagus."

Partisipan kedua merasa bahwa ia jarang untuk meluangkan waktu bermain bersama dengan kedua anaknya, ia menilai bahwa kedua anaknya sudah mampu untuk bermain sendiri dan terdapat pengasuh anak yang bisa menemani mereka bermain. Partisipan kedua lebih banyak membelikan mainan bagi kedua anaknya, dalam memilih permainan tersebut, ia bertanya kepada anak-anaknya mengenai mainan yang diinginkan. Akan tetapi dalam memilih permainan, partisipan kedua lebih banyak mempertimbangkan aspek kesenangan dan tidak memperhatikan aspek edukatif. Meskipun ia merasa bahwa nilai-nilai edukatif dalam permainan memiliki peranan penting, namun partisipan kedua terbiasa untuk mengandalkan sosok istri untuk mencarikan permainan yang memiliki nilai 
edukatif. Oleh karena itu, partisipan kedua merasa cenderung tidak mampu untuk melakukan tugas tersebut.

Kalau sekarang, saya beliin yang mereka mau aja saya udah gak bisa pikirin ada nilai edukasi buat mereka atau enggak. Gimana ya, harus ada orang yang bisa bantu saya kasih pertimbangan atau masukan. Kalau enggak, ya saya terbatas dengan mikir yang mereka mau aja. Karena kan istri bisa bantu mikir, punya pertimbangan lain

\section{Diskusi}

Pengalaman yang dimiliki oleh kedua partisipan sebagai ayah tunggal memiliki dampak yang cukup besar bagi fathering self-efficacy yang dimiliki (Sevigny, 2013). Peristiwa kematian istri membuat kedua partisipan cenderung mengalami kesulitan untuk merasa yakin terhadap beberapa dimensi tugas pengasuhan anak, hal tersebut salah satunya dapat disebabkan oleh kecenderungan mereka sebelumnya untuk mempercayakan istri dalam menjalankan peranan untuk mengasuh anak.

Anak mereka yang saat ini berada pada tahap perkembangan usia dini, cenderung membuat kedua partisipan sama-sama merasa kesulitan, dan hal tersebut turut berdampak pada fathering self-efficacy yang dimiliki. Banyaknya perilaku anak yang sulit membuat ayah menjadi tantangan bagi ayah tunggal untuk menjalankan peran pengasuhan anak, hal tersebut juga berkaitan dengan banyaknya pengalaman-pengalaman pertama anak dalam berbagai keterampilan dan perilaku (Jannah, 2015). Tidak adanya pasangan yang dapat memberikan bantuan informasi dan dukungan emosional kepada ayah tunggal membuat partisipan cenderung memiliki perasaan tidak kompeten dan mengalami kesulitan untuk mengasuh anak mereka, akibatnya penilaian yang dimiliki partisipan terhadap beberapa tugas pengasuhan cenderung negatif.

Dalam penelitian ini, terdapat beberapa faktor yang berperan terhadap fathering self-efficacy partisipan. Ketika salah satu partisipan sebagai ayah tunggal telah memiliki pengalaman sebelumnya, di mana mereka terlibat secara aktif dalam pengasuhan anak sejak anak mereka lahir, maka hal tersebut turut berperan terhadap adanya keyakinan yang lebih positif dalam dirinya (Salonen et al., 2009). Adanya pengalaman belajar, baik dari pengalaman sendiri maupun orang lain, membuat kedua partisipan mampu untuk mengevaluasi cara mereka menjalankan perannya sebagai ayah, termasuk sekarang menjadi ayah tunggal. 
Philanthropy Journal of Psychology

Vol 4 Nomor 1 (2020), 1-24

ISSN 2580-6076 (Print), ISSN 2580-8532 (Online)

Selain itu, bagaimana seorang laki-laki yang saat ini menjalankan perannya sebagai ayah memaknai perannya tersebut, turut berperan penting terhadap fathering self-efficacy yang dimiliki (Sevigny, 2010). Ketika ayah memaknai perannya secara lebih positif, maka ia akan cenderung lebih terdorong untuk terlibat secara aktif dan berusaha untuk menjalankan perannya dalam pengasuhan anak. Hal tersebut menyebabkan keyakinan yang dimiliki untuk menjalankan berbagai tugas pengasuhan menjadi cenderung lebih positif. Selain itu, apabila ayah tunggal memiliki kondisi emosional yang negatif, hal tersebut dapat menjadi hambatan bagi mereka untuk menjalankan tugas pengasuhan anak sebagai ayah tunggal. Ia cenderung dapat menjadi lebih pasif dan juga tidak merasa yakin terhadap kemampuannya untuk menjalankan peran sebagai ayah.

\section{Simpulan}

Berdasarkan hasil penelitian ini, masing-masing partisipan memiliki cara yang berbeda dalam mengoperasionalisasikan dimensi-dimensi dari fathering self- efficacy. Hal tersebut juga menunjukkan bahwa partisipan memiliki penilaian yang berbeda-beda terhadap kemampuan mereka untuk menjalankan berbagai tugas pengasuhan anak.

Pada delapan dimensi dari fathering self-efficacy, kedua partisipan memiliki penilaian terhadap keyakinan yang beragam. Salah satu partisipan merasa yakin untuk melakukan tugas pengasuhan pada kedelapan dimensi tersebut, sedangkan partisipan lainnya cenderung merasa tidak mampu. Penilaian tersebut direfleksikan melalui bagaimana kedua partisipan menjalankan perannya, satu partisipan secara aktif melakukan tugas-tugas pengasuhan tersebut, sedangkan partisipan lainnya cenderung jarang melakukan tugas tersebut dan menyerahkan tanggung jawab kepada pengasuh anak.

Pada satu dimensi yaitu instrumental care and routines, kedua partisipan cenderung merasa tidak mampu untuk melakukan tugas pengasuhan tersebut. Beberapa emosi seperti rasa lelah, tertekan, dan tidak mampu melakukan seorang diri membuat kedua partisipan cenderung merasa tidak yakin terhadap kemampuannya untuk menjalankan peran tersebut. Meskipun demikian salah satu partisipan tetap berusaha untuk melakukan tugas pengasuhan tersebut, sedangkan partisipan yang lain cenderung menyerahkan tanggung jawab sepenuhnya kepada pengasuh anak dan juga keluarga.

Terdapat beberapa faktor yang berperan terhadap penilaian yang dimiliki oleh kedua partisipan. Kurangnya pengalaman kedua partisipan untuk mengasuh anak secara langsung membuat keduanya cenderung merasa kurang terampil dan yakin akan 
kemampuannya. Akan tetapi, dengan adanya dorongan yang diberikan oleh pasangan maupun lingkungan sekitar berperan untuk mendorong kedua partisipan untuk melakukan tugas pengasuhan yang dimiliki. Selain itu melalui pengalaman pengasuhan di masa lalu maupun pengalaman orang lain, kedua partisipan dapat mengevaluasi dan mempertimbangkan bagaimana mereka melakukan pengasuhan di saat ini sebagai ayah tunggal.

Berdasarkan hasil penelitian ini, penelitian selanjutnya dapat mengeksplorasi secara lebih lanjut mengenai fathering self-efficacy pada tahap perkembangan yang berbeda dan juga pemaknaan peran ayah di budaya Indonesia. Selain itu, mengetahui bahwa ayah tunggal menghadapi begitu banyak tantangan dalam menjalani peran, penelitian selanjutnya dapat mengeksplorasi strategi-strategi untuk mendukung kesehatan mental seorang ayah tunggal. Hal tersebut dapat didukung oleh lingkungan sekitar ayah tunggal, dimana lingkungan sekitar dapat berperan dengan cara memberikan dukungan baik secara instrumental maupun secara moral. Keterlibatan ayah dalam pengasuhan juga penting untuk ditingkatkan dengan cara lebih melibatkan ayah dalam mengasuh anak dalam keluarga, hal tersebut dilakukan agar para ayah dapat memaknai perannya secara lebih positif serta menjadi lebih terampil dalam menjalankan perannya.

\section{Kepustakaan}

Andayani, \& Koentjoro. (2004). Psikologi keluarga: Peran ayah menuju coparenting. Yogyakarta: Citra Medika.

Bonanno, G. A. (2004). Loss, trauma, and human resilience: Have we underestimated the human capacity to thrive after extremely aversive events? American Psychologist, 59(1), 20-28. doi: 10.1037/0003-066X.59.1.20

Chiu, M., Rahman, F., Vigod, S., Lau, C., Cairney, J., \& Kurdyak, P. (2018). Mortality in single fathers compared with single mothers and partnered parents: A population-based cohort study. The Lancet Public Health 3(3), 1-9. doi: 10.1016/S2468-2667(18)300033 .

Coleman, P. K., \& Karraker, K. H. (2000). Parenting self-efficacy among mothers of schoolage children: Conceptualization, measurement, and correlates. Family Relations: An Interdisciplinary Journal of Applied Family Studies, 49(1), 13-24. doi: http://dx.doi.org/10.1111/j.1741-3729.2000.00013.x

Creswell, J. W. (2013). Qualitative inquiry \& research design: Choosing among five approaches. (3rd ed.). Thousand Oaks, CA: SAGE.

Dufur, M. J., Howell, N. C., Downey, D. B., Ainsworth, J. W., \& Lapray, A. J. (2010). Sex differences in parenting behaviors in single-mother and single-father 126 households. 
Journal of Marriage and Family, 72(5), 1092-1106. Diambil dari http://scihub.tw/10.1111/j.1741-3737.2010.00752.x

Hardyanti, S., Karmiyati, D., Hidayati, D. S. (2017). Parenting self-efficacy ayah pada nuclear dan extended family. Jurnal Ilmiah Psikologi Terapan. 5(2), 236-249. Diambil dari http://ejournal.umm.ac.id/index/php/iipt/article/viewFile/4939/4999

Heath, P. (2007). Parent-child relations: Context, research, and application. New Jersey: Pearson Education, Inc.

Jannah, M. (2015). Tugas-tugas perkembangan pada usia kanak-kanak. Gender Equality: International Journal of Child And Gender Studies. 1(2). Diambil dari http://jurnal.arraniry.ac.id/index.php/equality/article/view/792/622

Kong, K. A., \& Kim, S. I. (2015). Mental health of single fathers living in an urban community in South Korea. Comprehensive Psychiatry, 56, 188-197. doi: 10.1016/j.comppsych.2014.09.012

Mugove, K. (2017). Challenges encountered by single parents in the learning and development of children. International Journal of Scientific and Research Publications, 7(6). Diambil dari http://www.ijsrp.org/research-paper-0617/ijsrp- p6624.pdf

Murti, H. A. S. (2013). Efikasi diri ayah dalam pengasuhan anak usia dini. Dalam Murti, H. A. S. (Eds.), Prosiding dari Temu Ilmiah Nasional Psikologi Pendidikan Anak Usia Dini Tahun 2012. Universitas Kristen Satya Wacana: Salatiga.

Prasetyawati, I. (2018). Strategi coping pada ibu single parent (Skripsi, Universitas Muhammadiah Surakarta, Surakarta). Diambil dari http://eprints.ums.ac.id/61253/1/NASKAH\%20PUBLIKASI.pdf

Saikia, R. (2017). Broken family: Its causes and effects on the development of children. International Journal of Applied Research, 3(2), 445 - 448. Diambil dari http://www.allresearchjournal.com/archives/2017/vol3issue2/PartG/3-2-106798.pdf

Salonen, A. H., Kaunonen, M., Åstedt-Kurki, P., Järvenpää, A.-L., Isoaho, H., \& Tarkka, M.-T. (2009). Parenting self-efficacy after childbirth. Journal of Advanced Nursing, 65(11), 2324-2336. doi: 10.1111/j.1365-2648.2009.05113.x

Santrock, J. W. (2018). Life-span development. (17th ed.). Belmont, CA: McGraw-Hill Higher Education.

Septiani, D., \& Nasution, I. N. (2018). Peran keterlibatan ayah dalam pengasuhan bagi perkembangan kecerdasan moral anak. Jurnal Psikologi, 13(2), 120-125. doi: http://dx.doi.org/10.24014/jp.v13i2.4045.

Septiningsih, D. H. N. \& Cahyanti, I. Y. (2014). Psychological well-being pada ayah tunggal dengan anak penderita cerebral palsy. Jurnal Psikologi Klinis dan Kesehatan Mental, 3(1), 50-58.

Sevigny, P. R., \& Loutzenhiser, L. (2010). Predictors of parenting self-efficacy in mothers and fathers of toddlers. Child: Care, Health, and Development, 36(2), 179-189. doi: https://doi.org/10.1111/j.1365-2214.2009.00980.x 
ISSN 2580-6076 (Print), ISSN 2580-8532 (Online)

Sevigny, P. R., Loutzenhiser, L., \& McAuslan, P. (2016). Development and validation of the fathering self-efficacy scale. Psychology of Men \& Masculinity, 17(1), 92. Diambil dari http://psycnet.apa.org/record/2015-39673-001.

Willig, C. (2013). Introducing qualitative research in psychology. London: McGraw- Hill Education.

Wiludjeng, J. M. H. (2011). Orang tua tunggal: permasalahan dan solusinya. Jakarta: Inti Prima. 